\title{
Sınıf Öğretmeni Adaylarının Öğretmenlik Mesleğine İlişkin Tutumları ${ }^{1}$
}

\author{
DOI: 10.26466/opus.567283
}

\author{
Emel Tüzel İșeri* - Hilal Kahraman** - Nazife Karadağ ${ }^{* * *}$ \\ * Dr. Öğretim Üyesi, Tokat Gaziosmanpaşa Üniversitesi, Eğitim Fakültesi,/ Tokat / Türkiye \\ E-Posta: emeltuzel@hotmail.com \\ ORCID: $\underline{0000-0001-5638-0450}$ \\ ** Arş. Gör. Dr., Sivas Cumhuriyet Üniversitesi, Eğitim Fakültesi, Sivas/ Türkiye \\ E-Posta: hilalyucelkahraman@gmail.com \\ ORCID: 0000-0002-5680-8362 \\ *** Doç. Dr., Adıyaman Üniversitesi, Eğitim Fakültesi / Adıyaman/ Türkiye \\ E-Posta: nzfkrdg@hotmail.com \\ ORCID: 0000-0002-8194-4315
}

\section{Öz}

Tutum, kişinin bir psikolojik objeye karşı geliştirdiği duygu, düşünce ve davranışlarını oluşturan eğilimdir. Tutumların tek başına davranışı meydana getirdiği söylenemese de, davranışların temelinde belli bir tutumun varlı̆̆ından söz edilebilir. Bu çalışmanın amacı, öğretmen adaylarının öğretmenlik mesleğine ilişkin tutumlarını sahip oldukları çeşitli kişisel değişkenler açısından incelemektir. Betimsel tarama yöntemiyle gerçekleştirilen çalışmanın evrenini Türkiye'deki ü̧̧ farklı eğitim fakültesinin sınıf öğretmenliği programı 1. ve 4. sınıflarındaki 323 öğretmen adayı oluşturmaktadır. Veri toplama aracı olarak Üstüner (2006) tarafindan geliştirilen "Öğretmenlik Mesleğine Yönelik Tutum Ölçeği" kullanılmıştır. Araştırma sonuçları öğretmen adaylarının öğretmenlik mesleğine ilişkin tutumlarının cinsiyet, yaş, sını düzeyi, öğretmenlik mesleğini tercih sırası, aile desteğini alma durumları ve öğretmenlik mesleğini seçmek konusunda etkilendikleri kişiler açısından anlamlı farklılıklar gösterdiğini ortaya koymuştur. Sonuçlara göre kadın öğretmen adayları erkek öğretmen adaylarından; 1 . Sinıfta öğrenim görenler, 4. sinıftakilerden daha yüksek tutuma sahipken, yaş arttıkça tutumlarında azalma meydana gelmektedir. Öğretmenlik mesleğini tercih sırası önlerde olan, ailelerinin desteğini alan ve öğretmenlik mesleğini seçmede öğretmenlerinden etkilenen öğretmen adaylarının tutumları da daha yüksek düzeydedir.

Anahtar Kelimeler: Öğretmen adayları, ögretmenlik mesleği, tutum.

\footnotetext{
${ }^{1}$ Bu çalışma Kıbrıs'ta düzenlenen Vı. Uluslararası Eğitim Yönetimi Forumu'nda sunulan sözlü bildirinin genişletilmiş ve yeniden düzenlenmiş halidir
} 


\title{
Classroom Teacher Candidates'Attitudes towards Teaching Profession
}

\begin{abstract}
Attitude is the tendency that creates the emotions, thoughts and behaviors of a person against a psychological object. Although it cannot be said that only attitudes cause behavior, there is a certain attitude on the basis of behavior. The purpose of this study is to examine pre-service teachers' attitudes towards teaching profession in terms of various personal variables. Descriptive scanning method is carried out with the study universe of the work of three different faculties in Turkey who are undergoing training in the 1st and 4th grade class constitutes 323 teacher candidates. "Attitude Scale of Teaching Profession" developed by Üstüner (2006) was used as data collection tool. According to the research findings, it was found that teacher candidates' attitudes towards teaching profession showed significant differences in terms of gender, age, class level, preference of teaching profession, family support status and status of the teaching profession. According to the results, female teacher candidates had higher attitudes than male teacher candidates. 1st year students have higher attitudes than 4 th year students and attitudes decrease as age increases. The attitudes of the pre-service teachers who preferred the teaching profession, who received the support of their families, and who were affected by their teachers in choosing the teaching profession were also at a higher level.
\end{abstract}

Keywords: Teacher candidates, teaching profession, attitude. 


\section{Giriş}

Eğitim sisteminin başlıca öğeleri, öğretmenler, öğrenciler, yöneticiler ve eğitim programlarıdır. Eğitim sistemini oluşturan pek çok öğe içerisinde öğretmen, diğer öğeleri etkileme gücü açısından en önemli faktördür. Eğitim kalitesi ve niteliği büyük oranda öğretmene bağlıdır. Toplumsal kalkınma için nitelikli insanın yetiştirilmesinde, bireylerin toplumsal hayata hazırlanmasında öğretmenlerin rolleri son derece önemlidir. Meslek, Türk Dil Kurumu (TDK, 2019) tarafından "Belli bir eğitim ile kazanılan, sistemli bilgi ve becerilere dayalı, insanlara yararlı mal üretmek, hizmet vermek ve karşılığında para kazanmak için yapılan, kuralları belirlenmiş iş" olarak tanımlanmaktadır. Diğer taraftan öğretmenlik, 1739 sayılı Milli Eğitim Temel Kanunu'nda da belirtilediği şekliyle özel bir ihtisas mesleğidir. Nitekim Öğretmen Strateji Belgesi'nde de öğretmenlik mesleğinin, teknik bir uzmanlık alanı olarak sadece belirlenen amaçlar doğrultusunda öğrenci kılavuzluğunun gerçekleştirildiği bir iş kolu değil, evrensel değerlerin yüceltilerek yeniden üretildiği, toplumsal ve kültürel değerlerin yeni nesillere aktarıldığı saygın bir meslek olarak değerlendirilmiştir (MEB, 2017a). Benzer şekilde 2023 Eğitim Vizyonunda da öğretmenliğin önemine değinilmiş; eğitim sisteminde başta eğitim politikaları olmak üzere eğitim müfredatının, eğitimsel materyallerin, eğitim teknolojisi gibi alanlarda gerçekleştirilen her çeşit reformun ve iyileştirme çalışmalarına ilişkin başarının ve uygulanmasının, büyük oranda öğretmenlerin mesleki yeterliliklerine, algılarına ve adanmışlıklarına bağlı olduğu vurgulanmıştır (MEB, 2018). Bu yönüyle eğitim sisteminin en stratejik öğesi olarak öğretmenlik, diğer meslek gruplarına oranla daha seçkin özellikler taşımalıdır. Ayrıca öğretmenliğin, özel bir uzmanlık bilgisine ve becerisine ihtiyaç duyan bir meslek olarak kabul görmesi (MEB, 1973), bu mesleği yapmak isteyen kişilerin de belirli yeterliliklere sahip olmasın gerektirir.

“Öğretmenlerin, mesleklerini etkili ve verimli bir biçimde icra edebilmeleri için sahip olmaları gereken bilgi, beceri ve tutumlar" şeklinde tanımlanan (MEB, 2017b) öğretmen yeterlilikleri, sadece genel kültüre, alan bilgisine ve öğretmenlik meslek bilgisine sahip olmak ile açıklanamaz; bunun yanında öğretmenlerin duyuşsal tepkileri ve mesleğine karşı geliştirdikleri tutumlar da öğretmenlik mesleğinin 
başarısında önemli bir rol oynar. Nitekim Öğretmenlik Mesleği Genel Yeterliliklerinde de "Tutum ve Değerler", "Mesleki Bilgi" ve "Mesleki Beceri" alanlarıla birlikte bir yeterlik alanı olarak belirlenmiştir (MEB, 2017b).

Tutum, kişinin bir psikolojik objeye karşı geliştirdiği duygu, düşünce ve davranışlarını oluşturan eğilimdir. Tutumların tek başına davranışı meydana getirdiği söylenemese de, davranışların temelinde belli bir tutumun varlığından söz edilebilir. Bir başka deyişle tutumların kendi başına gözlenemeyen fakat gözlenebilen kimi davranışlara neden olduğu varsayılan eğilimler olduğu söylenebilir (Kağıtçıbaşı, 2006, s. 107). Bu yönüyle değerlendirildiğinde öğretmenlerin öğretmenlik mesleğine karşı tutumlarının, mesleklerini başarılı bir şekilde icra etmelerinde önemli bir rolü olduğu (Erdem, Gezer ve Çokadar, 2005, s. 471) söylenebilir. Bu bağlamda öğretmenlerden beklenen manevi ve evrensel değerleri gözetme, öğrencilerin gelişimini destekleyici tutum sergileme, öğrenci, meslektaş, aile ve eğitimin diğer paydaşlarıyla etkili iletişim ve işbirliği kurma ve kişisel ve mesleki gelişimine ilişkin çalışmalara katılma (MEB, 2017b) rollerinin yerine getirilebilmesi, öğretmenlerin mesleklerine karş1 olumlu tutum geliştirmeleriyle olanaklı olabilir. Yine öğretmenlerin yaptıkları mesleği sevmeleri ve bağlı olmaları, toplum tarafından yaptıkları mesleğin gerekli ve önemli kabul edildiğini hissetmeleri ve kendilerini devamlı olarak geliştirmeleri bu mesleğe ilişkin tutumlarıla ilişkilidir (Temizkan, 2008).

Öğretmenlik mesleğine karşı gelişen tutumun mesleğe başlamadan ve hatta öğretmen yetiştirmeye ilişkin programlara öğrenci alınmasından önce belirlenmesi faydalı olabilir. Çünkü öğretmen adaylarının kişilik özellikleri ve mesleklerine karşı geliştirdikleri tutumları da, mesleklerini en iyi şekilde gerçekleştirmelerinde en az akademik başarıları kadar etkili olacaktır. Bu anlamda "Öğretmenlik mesleğine giriş sürecinde çok sayıda veri kaynağına bağlı bir değerlendirmenin esas alındığı seçme sistemlerinin geliştirilmesi" (MEB, 2017a) önemli bir adım olarak kabul edilebilir.

İlgili alan yazında öğretmenlik mesleğine ilişkin tutumların öğretmen adayları örnekleminde farklı yıl ve türde gerçekleştirilen araştırmalar (Akpınar, Yıldız ve Ergin, 2006; Alım ve Bekdemir, 2006; Bozdoğan, Aydın ve Yıldırım, 2007; Çelenk, 1988; Çetinkaya, 2009; Brown, 1992; Su, 
1997; Üstün, Erkan ve Akman, 2004; Dikmen ve Tuncer, 2018; Durmuşoğlu, Yanık ve Akkoyunlu, 2009; Serdar, Harmandar-Demirel ve Demirel, 2018; Uğurlu ve Polat, 2011) olmakla birlikte, öğretmen adaylarının öğretmenlik mesleğine ilişkin tutumları ile akademik motivasyon ve akademik başarıları (Zembat, Akşın-Yavuz, Tunçeli ve Yılmaz, 2018), mesleki kaygı düzeyleri (Akgün ve Özgür, 2014), bilgi okuryazarlık öz yeterliği inancı ve üst biliş düşünme becerileri (Dikmen ve Tuncer, 2018b), mesleği tercih nedenleri (Nalçacı ve Sökmen, 2016), öğrenme stilleri (Çiğdem ve Memiş, 2011; Kahyaoğlu, Tan ve Kaya, 2013), akademik sahtekarlık eğilimleri (Hançer, 2017, suçları (Toprakçı, 2009) gibi çok farklı değişkenler arasındaki ilişkileri inceleyen çalışmalar yapıldığ 1 görülmektedir. Tutumların, öğrenildikleri gibi kalmadıkları ve zaman içerisinde gelişme ve değişme gösterebildikleri (Kağıtçıbaşı, 2006, s. 122) düşünüldüğünde, bu ve benzeri çalışmaların sonuçlarının, öğretmen adaylarının öğrenme yaşantılarının öğretmenlik mesleğine ilişkin olumlu tutum oluşturacak biçimde düzenlenmesine ve öğretmen adaylarının tutumlarının olumlu yönde değiştirilmesi yönünde desteklenmelerine katkı sağlayacağı umulmaktadır.

\section{Araştırmanın Amacı}

$\mathrm{Bu}$ araştırmanın amacl, sınıf öğretmeni adaylarının öğretmenlik mesleğine ilişkin tutumları ve sahip oldukları kişisel değişkenler açısından incelenmesidir. Bu amaçla aşağıda yer alan sorulara cevap aranmıştır:

Sınıf öğretmenliği programında öğrenim gören öğretmen adaylarının öğretmenlik mesleğine ilişkin tutumları:

1. Sınıf öğretmeni adaylarının öğretmenlik mesleğine ilişkin tutumları nedir?

2. Sınıf öğretmeni adaylarının öğretmenlik mesleğine ilişkin tutumları ve sahip oldukları kişisel (bazı) değişkenlere göre farklılaşmakta mıdır?

a) Cinsiyetlerine,

b) Yaşlarına,

c) Bulundukları sinıf düzeylerine,

d) Ailelerinde öğretmen bulunup bulunmamasına, 
e) Yükseköğretime geçiş sınavı tercihlerinde öğretmenlik bölümlerini tercih sırasına,

f) Öğrenim gördükleri üniversiteye,

g) Ailelerindeki öğretmenlerin yakınlık derecelerine,

h) Öğretmenlik mesleğini seçmelerinde ailelerinin desteğine,

i) Öğretmenlik mesleğini seçmelerinde en fazla etkisinde kaldıkları kişilere göre anlamlı farklılık göstermekte midir?

\section{Yöntem}

\section{Araştırma Modeli}

$\mathrm{Bu}$ çalışma, sınıf öğretmenliği programında öğrenim gören öğretmen adaylarının öğretmenlik mesleğine ilişkin tutumlarının sahip oldukları çeşitli kişisel değişkenlere göre nasıl değiştiğini inceyen betimsel tarama modelinde bir araştırmadır. Karasar (2009) betimleme yöntemini "Olay, obje, varlık, kurum, grup ve çeşitli alanların "ne" olduğunu açıklamaya çalışmak" şeklinde tanımlamaktadır.

\section{Çalışma Evreni}

Çalışma evrenini kolay ulaşılabilir olması açısından seçilmiş Türkiye'deki 3 farklı eğitim fakültesinde, sınıf düzeyinde ölçüt örnekleme yöntemi ile araştırmaya dahil edilen 1 . ve 4. sınıflarında öğrenim görmekte olan toplam 323 sınıf öğretmeni adayı oluşturmaktadır. Araştırma örnekleminde yer alan öğretmen adaylarına ilişkin kişisel bilgiler, Tablo 1'de yer almaktadir.

Tablo 1 incelendiğinde öğretmen adaylarının 251'inin kadın $(\% 77,7)$; $82^{\prime} \operatorname{sinin}(\% 25,4) 18$ yaşında; $177^{\prime} \operatorname{sinin}(\% 54,8) 1$. sınıf öğrencisi ve $126^{\prime}$ sının (\%39) A üniversitesinde öğrenim görmekte olduğu; 182'sinin (\%56,3) sinıf öğretmenliğini 1 . sırada tercih ettiği; 170 'inin $(\% 52,6)$ ailesinde öğretmenlik mesleğini yapan biri olduğu; 102 'sinin $(\% 31,6)$ ailedeki öğretmenin yakınlık derecesinin ise amca, hala, dayı, teyze olmak üzere 3. dereceden akrabalar olduğu; 128'inin $(\% 39,6)$ öğretmen olmalarındaki aile desteğinin pek çok düzeyinde ve 152 'sinin $(\% 47,1)$ öğretmen olmada en çok etkilendikleri kişinin ise anne-babası olduğu görülmektedir. 
Tablo 1. Örneklemde Yer Alan Öğretmen Adaylarmnn Kişisel Özelliklerine Ait Bulgular $(\mathrm{N}=323)$

\begin{tabular}{|c|c|c|c|}
\hline Değişkenler & & $\mathbf{n}$ & $\%$ \\
\hline \multirow{2}{*}{ Cinsiyet } & Kadın & 251 & 77.7 \\
\hline & Erkek & 72 & 22.3 \\
\hline \multirow{9}{*}{ Yaş } & 17 & 5 & 1.5 \\
\hline & 18 & 82 & 25.4 \\
\hline & 19 & 59 & 18.3 \\
\hline & 20 & 29 & 9.0 \\
\hline & 21 & 51 & 15.8 \\
\hline & 22 & 49 & 15.2 \\
\hline & 23 & 28 & 8.7 \\
\hline & 24 & 16 & 5.0 \\
\hline & 25 & 4 & 1.2 \\
\hline \multirow{2}{*}{ Sınıf Düzeyi } & 1. Sinif & 177 & 54.8 \\
\hline & 4. Sinif & 146 & 45.2 \\
\hline \multirow{3}{*}{ Üniversite } & A Üniversitesi & 126 & 39.0 \\
\hline & B Üniversitesi & 99 & 30.7 \\
\hline & C Üniversitesi & 98 & 30.3 \\
\hline \multirow{4}{*}{ Tercih Sırası } & 1 & 182 & 56.3 \\
\hline & $2-5$ & 67 & 20.7 \\
\hline & 6-10 & 37 & 11.5 \\
\hline & 11 ve üzeri & 37 & 11.5 \\
\hline \multirow{2}{*}{$\begin{array}{l}\text { Ailede Öğretmen } \\
\text { Olma Durumu }\end{array}$} & Var & 170 & 52.6 \\
\hline & Yok & 153 & 47.4 \\
\hline \multirow{5}{*}{$\begin{array}{l}\text { Ailedeki } \\
\text { Öğretmenlerin } \\
\text { Yakınlık Derecesi }\end{array}$} & 1 derece (Anne. baba) & 11 & 3.4 \\
\hline & 2 derece (Kardeş. büyükanne-büyükbaba) & 32 & 9.9 \\
\hline & 3derece (Amca. hala. dayı. teyze) & 102 & 31.6 \\
\hline & Birden çok (1-2. 1-3. 2-3 veya 1-2-3 derece) & 25 & 7.6 \\
\hline & Yok & 153 & 47.4 \\
\hline \multirow{5}{*}{$\begin{array}{l}\text { Öğretmen } \\
\text { Olmaya } \\
\text { Aile Desteği }\end{array}$} & Hiç & 15 & 4.6 \\
\hline & $\mathrm{Az}$ & 11 & 3.4 \\
\hline & Orta & 80 & 24.8 \\
\hline & Çok & 89 & 27.6 \\
\hline & Pek çok & 128 & 39.6 \\
\hline \multirow{6}{*}{$\begin{array}{l}\text { Öğretmen Olmada } \\
\text { En } \\
\text { Fazla Etkilendikleri } \\
\text { Kişi }\end{array}$} & Anne-baba & 152 & 47.1 \\
\hline & Kardeş & 7 & 2.2 \\
\hline & Diğer akraba & 24 & 7.4 \\
\hline & Öğretmen & 60 & 18.6 \\
\hline & Arkadaş & 21 & 6.5 \\
\hline & Diğer & 59 & 18.3 \\
\hline
\end{tabular}




\section{Veri Toplama Aracı}

Veri toplama aracı iki kısımdan oluşmaktadır. İlk kısımda yer alan öğretmen adaylarının demografik bilgilerini içeren "kişisel değişkenler" formu araştırmanın alt problemlerine uygun olarak araştırmacılar tarafından oluşturulmuştur. Veri toplama aracının ikinci kısmında ise Üstüner (2006) tarafından geliştirilen "Öğretmenlik Mesleğine Yönelik Tutum Ölçeği" yer almaktadır. Ölçek, öğretmenlik mesleğine ilişkin tutumları belirleyen 34 maddeden oluşan, tek faktörlü yapıdadır. Ölçek 24 olumlu 10 olumsuz tutum ifadesi içermektedir. Üstüner (2006) tarafından 449 öğrenci üzerinde gerçekleştirilen çalışmada ölçeğin faktör yük değerlerinin .74-.41 arasında değiştiği belirlenmiştir. Yapılan bu çalışma için Cronbach Alpha güvenirlik katsayısı ise .9542 olarak hesaplanmıştır.

\section{Verilerin Toplanması ve Analizi}

Veri toplama aracının uygulanması aşamasında öğrencilerin sorularına cevap verebilmek amacıyla araştırmacılar öğrencilerin yanında bulunmuştur. Araştırma verileri toplanırken öğrencilerden isim veya kimliklerini belirten kişisel bilgi istenmemiştir. Verilerin analiz edilmesinde ise SPSS 22.0 paket program kullanılmıştır. Veri analizinde frekans (f), ortalama puan $(\bar{X})$, yüzde (\%), standart sapma (S), tek yönlü varyans analizi (ANOVA), t-testi, korelasyon katsayısı hesaplaması, Kruskal Wallis $\mathrm{H}$ - testi ve Mann Whitney $\mathrm{U}$ testleri kullanılmıştır.

\section{Bulgular}

Araştırmanın birinci alt problemi "Sınıf öğretmeni adaylarının öğretmenlik mesleğine yöneilk tutumları nedir" şeklinde belirlenmiştir. Bu alt problemi çözümlemek amacıyla gerçekleşirilen analiz sonuçları aşağıda yer almaktadir. 
Tablo 2. Sını Öğretmeni Adaylarının Öğretmenlik Mesleğine İlişkin Tutum Düzeylerine Ait Min, Max, Ortalama Puan $(\bar{X})$ ve Standart Sapma (S) Değerleri

\begin{tabular}{lccccl}
\hline Tutum & $\mathbf{n}$ & Min & Max & $\overline{\mathbf{X}}$ & $\mathbf{S}$ \\
\hline Toplam & 323 & 1,18 & 5,00 & 3,9872 &, 73682 \\
\hline
\end{tabular}

Tablo 2 incelendiğinde, araştırmada yer alan tüm öğetmen adaylarının öğretmenlik mesleğine yönelik tutumlarının $\bar{X}=1,18$ (hiç katılmıyorum) ve $\overline{\mathrm{X}}=5,00$ (tamamen katıllyorum) arasında değiştiği ve $\overline{\mathrm{X}}=3.98$ (çoğunlukla katılıyorum) ortalama puana sahip olduğu görülmektedir. Buna göre öğretmen adaylarının genel olarak öğretmenlik mesleğine yönelik olumlu bir tutuma sahip iken, mesleğe ilişkin oldukça olumsuz tutuma sahip öğretmen adaylarının da bulunduğu söylenebilir.

Araştırmanın ikinci alt problemi "Sınıf öğretmeni adaylarının öğretmenlik mesleğine ilişkin tutumları ve sahip oldukları kişisel (bazı) değişkenlere göre farklılaşmakta mıdır?" şeklinde belirlenmiştir. Yapılan analiz sonuçları ve elde edilen bulgular aşağıda sırasıyla yer almaktadır. Sınıf öğretmeni adaylarının cinsiyetleri açısından öğretmenlik mesleğine ilişkin tutum düzeyleri Tablo 3'te verilmiştir.

Tablo 3. Sınıf Öğretmeni Adaylarının Cinsiyetleri Açısından Öğretmenlik Mesleğine İlişkin Tutum Düzeylerine Ait Bağımsız T-Testi Sonuçlan

\begin{tabular}{lllllll}
\hline Cinsiyet & $\mathbf{n}$ & $\overline{\mathbf{X}}$ & $\mathbf{S}$ & $\mathbf{t}$ & sd & p \\
\hline Kadın & 251 & 4,0334 &, 75301 & 2,115 & \multirow{2}{*}{321} & \multirow{2}{*}{$035^{*}$} \\
\hline Erkek & 72 & 3,8262 &, 65709 & & & \\
\hline
\end{tabular}

Tablo 3 incelendiğinde, öğretmen adaylarının öğretmenlik mesleğine ilişkin tutumlarının cinsiyetleri açısından anlamlı olarak farklılaştığı görülmektedir $\left(t_{(321)}=2,115, p<.05\right)$. Kadın öğretmen adaylarının öğretmenlik mesleğine ilişkin tutumları $(\overline{\mathrm{X}}=4,0334)$, erkek öğretmen adaylarınınkinden $(\overline{\mathrm{X}}=3,8262)$ daha yüksek olduğu görülmektedir.

Sınıf öğretmeni adaylarının yaşları ile öğretmenlik mesleğine ilişkin tutumları arasındaki ilişki Tablo 4'te yer almaktadır.

Tablo 4'te yer alan sınıf öğretmeni adaylarının yaşları ile öğretmenlik mesleğine ilişkin tutum düzeyleri arasındaki ilişki incelendiğinde, yaş ile tutum düzeyleri arasında negatif yönlü, düşük düzeyde ve anlamlı bir ilişki olduğu ortaya koyulmuştur. Buna göre öğretmen adaylarının yaşları 
arttıkça öğretmenlik mesleğine ilişkin tutumlarında düşük düzeyde de olsa anlamlı bir azalma meydana geldiği söylenebilir ( $r=-.130, \mathrm{p}<.05)$.

Tablo 4. Sinıf Öğretmeni Adaylarının Yaşları İle Öğretmenlik Mesleğine İlişkin Tutumlarn Arasindaki Korelasyonlar $(\mathrm{N}=323)$

\begin{tabular}{lllll}
\hline Değişkenler & $\bar{X}$ & S & $\mathbf{1}$ & $\mathbf{2}$ \\
\hline 1. Yaş & 20,2446 & 1,98416 & 1 &,$- 130\left(^{*}\right)$ \\
\hline 2.Tutum Düzeyi & 3,9872 &, 73682 & & 1 \\
\hline
\end{tabular}
${ }^{* *} p<.01,{ }^{*} p<.05$

Sınıf öğretmeni adaylarının sınıf düzeylerine göre öğretmenlik mesleğine ilişkin tutumları Tablo 5 'te yer almaktadır.

Tablo 5. Sinıf Öğretmeni Adaylarının Sınıf Düzeylerine Göre Öğretmenlik Mesleğine İlişkin Tutum Dïzeylerine Ait Bağımsız T-Testi Sonuçları

\begin{tabular}{cllllll}
\hline Sinıf Düzeyi & $\mathbf{n}$ & $\overline{\boldsymbol{X}}$ & $\mathbf{S}$ & $\mathbf{t}$ & $\mathbf{S d}$ & $\mathbf{p}$ \\
\hline 1. Sinıf & 177 & 4,0618 &, 76434 & \multirow{2}{*}{2,013} & \multirow{2}{*}{321} & \multirow{2}{*}{, $045^{*}$} \\
\hline 4. Sinıf & 146 & 3,8968 &, 69387 & & & \\
\hline
\end{tabular}

Tablo 5'te yer alan sınıf öğretmeni adaylarının öğrenim gördükleri sınıf düzeyleri açısından öğretmenlik mesleğine ilişkin tutumları incelendiğinde, 1 . sınıf öğrencilerinin tutumlarının 4. sınıf öğrencilerinin tutumlarına göre anlamlı olarak daha yüksek düzeyde olduğu görülmektedir $\left(\mathrm{t}_{(321)}=2,013, \mathrm{p}<.05\right)$.

Sınıf öğretmeni adaylarının ailesinde öğretmen bulunup bulunmamasına göre öğretmenlik mesleğine ilişkin tutumları Tablo 6'da yer almaktadır.

Tablo 6. Sinıf Öğretmeni Adaylarının Ailesinde Öğretmen Bulunup Bulunmamasına Göre Öğretmenlik Mesleğine İlişkin Tutum Düzeylerine Ait Bă̆gmsız T-Testi Sonuçları

\begin{tabular}{llrllll}
\hline A.Ö.Olma D. & $\mathbf{n}$ & $\overline{\boldsymbol{X}}$ & $\mathbf{S}$ & $\mathbf{t}$ & $\mathbf{S d}$ & $\mathbf{p}$ \\
\hline Evet & 170 & 4,0156 &, 77474 & \multirow{2}{*}{, 729} & \multirow{2}{*}{321} & \multirow{2}{*}{467} \\
\hline Hayır & 153 & 3,9557 &, 69343 & & & \\
\hline
\end{tabular}


Tablo 6'da görüldüğü üzere, öğretmen adaylarının ailesinde öğretmen olup olmaması ile öğretmenlik mesleğine ilişkin tutumları arasında anlamlı bir ilişkiye rastlanmamıştır $\left(\mathrm{t}_{(321)}=, 729, \mathrm{p}>.05\right)$.

Sınıf öğretmeni adaylarının üniversite sınavı sonucunda öğretmenlik tercih sıralarına göre öğretmenlik mesleğine ilişkin tutumları Tablo 7'de yer almaktadir.

Tablo 7. Sinı Ö̈̆retmeni Adaylarınn Üniversite Sınavı Sonucunda Öğretmenlik Tercih Straları İle Öğretmenlik Mesleğine İlişkin Tutumlarn Arasındaki Korelasyonlar

\begin{tabular}{lllll}
\hline Değisskenler & $\overline{\boldsymbol{X}}$ & $\mathrm{S}$ & $\mathbf{1}$ & $\mathbf{2}$ \\
\hline 1. Tercih S1rası & 4,1022 & 5,56599 & 1 &,$- 168^{* *}$ \\
\hline 2.Tutum Düzeyi & 3,9872 &, 73682 & & 1 \\
\hline${ }^{* *} p<.01,{ }^{*} p<.05$ & & & &
\end{tabular}

Tablo 7 incelendiğinde, sınıf öğretmeni adaylarının üniversite sınavı sonucunda öğretmenlik tercih sırası arttıkça, öğretmenlik mesleğine ilişkin tutumlarında düşük düzeyde ancak anlamlı bir azalma meydana geldiği görülmektedir. Bir diğer ifade ile öğretmenlik mesleğini tercih sırası önlerde olan öğretmen adaylarının mesleğe ilişkin tutumlarının düşük düzeyde de olsa anlamlı olarak daha olumlu olduğu söylenebilir $(\mathrm{r}=-.168, \mathrm{p}<.01)$.

Sınıf öğretmeni adaylarının öğrenim gördükleri üniversiteye göre öğretmenlik mesleğine ilişkin tutumları Tablo 8'de yer almaktadır.

Tablo 8. Sını Öğretmeni Adaylarını Öğrenim Gördükleri Üniversiteye Göre Öğretmenlik Mesleğine İlişkin Tutum Düzeylerine Ait Tek Yönlï Varyans Analizi (ANOVA) Sonuçları

\begin{tabular}{|c|c|c|c|c|c|c|c|c|c|}
\hline Üni. & $\mathrm{n}$ & $\overline{\boldsymbol{X}}$ & $S$ & & $\begin{array}{l}\text { Kare. } \\
\text { Top. }\end{array}$ & Sd & $\begin{array}{l}\text { Kare. } \\
\text { Ort. }\end{array}$ & $\mathbf{F}$ & $p$ \\
\hline A & 126 & 4,0652 & ,70307 & G.Ar. & 2,870 & 2 & 1,435 & \multirow{4}{*}{2,671} & \multirow{4}{*}{ 071, } \\
\hline B & 99 & 3,8473 & ,75326 & G.İंci & 171,944 & 320 &, 537 & & \\
\hline C & 98 & 4,0282 & 74991 & Top. & 174,814 & 322 & & & \\
\hline Top. & 323 & 3,9872 & ,73682 & & & & & & \\
\hline
\end{tabular}


Tablo 8 incelendiğinde, öğretmen adaylarının mesleğe yönelik tutumlarının öğrenim gördükleri üniversiteye göre istatistikî olarak farklılaşmadı ğı ortaya koyulmuştur $\left(\mathrm{F}_{(2-320)}=2,271, \mathrm{p}>.05\right)$.

Sınıf öğretmeni adaylarının ailelerindeki öğretmenlerin yakınlık derecelerine göre öğretmenlik mesleğine ilişkin tutumları Tablo 9'da yer almaktadır.

Tablo 9. Sınıf Öğretmeni Adaylarının Öğretmenlik Mesleğine İlişkin Tutumlarının Ailelerindeki Öğretmenlerin Yakınlık Derecelerine Göre Değişimine Ait Sıra Ortalamaları ve Kruskal Wallis H-Testi Sonuçları

\begin{tabular}{lllll}
\hline \multirow{2}{*}{ Öğretmenin Yakınlık Derecesi } & \multicolumn{3}{l}{ Mesleğe İlişkin Tutum } & \\
\cline { 2 - 3 } & $\mathbf{n}$ & SıraOrt. & $\mathbf{X}^{\mathbf{2}}$ & $\mathbf{p}$ \\
\hline 1. derece (Anne, baba) & 11 & 99,68 & & \\
\cline { 1 - 3 } 2.derece (Kardeş, büyükanne-büyükbaba) & 32 & 76,52 & \multirow{2}{*}{, 565} \\
\cline { 1 - 3 } 3. derece (Amca, hala, dayı, teyze) & 102 & 86,57 & \\
\hline Birden çok (1-2, 1-3, 2-3 veya 1-2-3 derece) & 25 & 86,38 & & \\
\hline Toplam & 170 & & & \\
\hline
\end{tabular}

Tablo 9'da yer aldığı üzere, sınıf öğretmeni adaylarının öğretmenlik mesleğine ilişkin tutumlarının, ailelerindeki öğretmenlerin yakınlık derecelerine göre istatistikî olarak anlamlık farklılık göstermediği belirlenmiştir $\left[\mathrm{X}^{2}(3)=2,037, \mathrm{p}>\right.$.05].

Sınıf öğretmeni adaylarının öğretmenlik mesleğini seçmelerinde aile desteğine göre öğretmenlik mesleğine ilişkin tutumları Tablo 10'da yer almaktadır.

Tablo 10. Sını Öğretmeni Adaylarının Öğretmenlik Mesleğini Seçmelerinde Aile Desteği İle Öğretmenlik Mesleğine İlişkin Tutumlan Arasındaki Korelasyonlar $(\mathrm{N}=323)$

\begin{tabular}{lll}
\hline Değişkenler & $\mathbf{1}$ & $\mathbf{2}$ \\
\hline 1. Aile Desteği & 1 &, $204^{* *}$ \\
\hline 2.Tutum Düzeyi & & 1 \\
\hline${ }^{* *} p<.01,{ }^{*} p<.05$ & &
\end{tabular}


Tablo 10'da görüldüğü üzere, öğretmen adaylarının öğretmenlik mesleğini seçmelerinde ailelerinin desteğini alma düzeyleri arttıkça, öğretmenlik mesleğine ilişkin tutumlarında pozitif yönde, düşük düzeyde, anlamlı bir artış meydana gelmektedir $(\mathrm{r}=.204, \mathrm{p}<.01)$.

Sınıf öğretmeni adaylarının öğretmenliği tercih etmelerinde en fazla etkisinde kaldıkları kişiye göre öğretmenlik mesleğine ilişkin tutumları Tablo 11, 12 ve 13'te yer almaktadır.

Tablo 11. Sınıf Öğretmeni Adaylarının Öğretmenlik Mesleğine İlişkin Tutumlarının Öğretmenliği Tercih Etmelerinde En Fazla Etkisinde Kaldıkları Kişiye Göre Değişimine Ait Sıra Ortalamaları ve Kruskal Wallis H-Testi Sonuçları

\begin{tabular}{|c|c|c|c|c|}
\hline \multirow{2}{*}{$\begin{array}{l}\text { En Fazla } \\
\text { Etkide Bulunan Kişi }\end{array}$} & \multicolumn{4}{|c|}{ Öğretmenlik Mesleğine İlişkin Tutum } \\
\hline & $\mathrm{n}$ & Sira Ort. & $\mathrm{X}^{2}$ & $\mathrm{p}$ \\
\hline Anne-baba & 152 & 167,01 & \multirow{7}{*}{21,925} & \multirow{6}{*}{, $001^{*}$} \\
\hline Kardeş & 7 & 91,21 & & \\
\hline Diğer akraba & 24 & 130,54 & & \\
\hline Öğretmen & 60 & 199,53 & & \\
\hline Arkadaş & 21 & 126,50 & & \\
\hline Diğer & 59 & 144,76 & & \\
\hline Toplam & 323 & & & \\
\hline
\end{tabular}

Tablo 11 incelendiğinde, öğretmen adaylarının öğretmenlik mesleğine ilişkin tutumlarının öğretmenlik mesleğini tercih etmelerinde en fazla etkilerinde kaldıkları kişiye göre anlamlı olarak değiştiği ortaya koyulmuştur $\left[\mathrm{X}^{2}(5)=21,925, \mathrm{p}<.01\right]$. Anlamlı farklılığın hangi ikili gruplar arasında ortaya çıktığını belirlemeye ilişkin olarak yapılan T-testi ve Mann Whitney U testleri Tablo 12 ve Tablo 13'te yer almaktadır.

Tablo 12. Anlamlı Farkın Bulunduğu Gruplar T-testi Sonuçları

\begin{tabular}{lllllll}
\hline Gruplar & $\mathbf{n}$ & $\overline{\boldsymbol{X}}$ & $\mathbf{S}$ & $\mathbf{t}$ & $\mathbf{S d}$ & $\mathbf{p}$ \\
\hline Anne-baba & 152 & 4,0216 &, 74179 & \multirow{2}{*}{$-2,195$} & 210 & \multirow{2}{*}{$030^{*}$} \\
\hline Öğretmen & 60 & 4,2532 &, 67139 & & & \\
\hline Anne-baba & 152 & 4,0216 &, 74179 & 1,044 & 209 & \multirow{2}{*}{298} \\
\hline Diğger & 59 & 3,9078 &, 62150 & & \\
\hline Öğretmen & 60 & 4,2532 &, 67139 & 2,913 & \multirow{2}{*}{117} & \multirow{2}{*}{$004^{*}$} \\
\hline Diğger & 59 & 3,9078 &, 62150 & & &
\end{tabular}


Tablo 12'de yer alan T-testi sonuçları incelendiğinde öğretmenlerinin etkisinde kalan öğretmen adaylarının, anlamlı olarak anne-babalarının $\left(t_{(210)}=2,195, p<.05\right)$ ve diğer kişilerin $\left(t_{(117)}=2,913, p<.01\right)$ etkisinde bulunan öğretmen adaylarından daha yüksek düzeyde tutuma sahip oldukları belirlenmiştir.

Tablo 13. Anlamlı Farklılı̆̆ın Bulunduğu Gruplar Mann Whitney U Testi Sonuçları

\begin{tabular}{|c|c|c|c|c|c|}
\hline Gruplar & $\mathbf{n}$ & Sira Ort. & Sira Toplamı & $\mathbf{U}$ & $\mathbf{p}$ \\
\hline Anne-baba & 152 & 81.61 & 12404.00 & \multirow{2}{*}{288.00} & \multirow{2}{*}{$.040^{*}$} \\
\hline Kardeş & 7 & 45.14 & 316.00 & & \\
\hline Anne-baba & 152 & 91.09 & 13845.00 & \multirow{2}{*}{1431.00} & \multirow{2}{*}{.090} \\
\hline Diğer akraba & 24 & 72.13 & 1731.00 & & \\
\hline Anne-baba & 152 & 89.60 & 13619.00 & \multirow{2}{*}{1201.00} & \multirow{2}{*}{.066} \\
\hline Arkadaş & 21 & 68.19 & 1432.00 & & \\
\hline Kardeş & 7 & 13.29 & 93.00 & \multirow{2}{*}{65.000} & \multirow{2}{*}{.369} \\
\hline Diğer akraba & 24 & 16.79 & 403.00 & & \\
\hline Kardeş & 7 & 14.86 & 104.00 & \multirow{2}{*}{76.000} & \multirow{2}{*}{$.006^{*}$} \\
\hline Öğretmen & 60 & 36.23 & 2174.00 & & \\
\hline Kardeş & 7 & 12.14 & 85.00 & \multirow{2}{*}{57.00} & \multirow{2}{*}{.381} \\
\hline Arkadaş & 21 & 15.29 & 321.00 & & \\
\hline Kardeş & 7 & 21.79 & 152.50 & \multirow{2}{*}{124.50} & \multirow{2}{*}{.088} \\
\hline Diğer & 59 & 34.89 & 2058.50 & & \\
\hline Diğer akraba & 24 & 29.50 & 708.00 & \multirow{2}{*}{408.00} & \multirow{2}{*}{$.002^{*}$} \\
\hline Öğretmen & 60 & 47.70 & 2862.00 & & \\
\hline Diğer akraba & 24 & 23.27 & 558.50 & \multirow{2}{*}{245.50} & \multirow{2}{*}{.886} \\
\hline Arkadaş & 21 & 22.69 & 476.50 & & \\
\hline Diğer akraba & 24 & 38.85 & 932.50 & \multirow{2}{*}{632.50} & \multirow{2}{*}{.448} \\
\hline Diğer & 59 & 43.28 & 2553.50 & & \\
\hline Öğretmen & 60 & 45.51 & 2730.50 & \multirow{2}{*}{359.50} & \multirow{2}{*}{$.004^{*}$} \\
\hline Arkadaş & 21 & 28.12 & 590.50 & & \\
\hline Arkadaş & 21 & 36.21 & 760.50 & \multirow{2}{*}{529.50} & \multirow{2}{*}{.325} \\
\hline Diğer & 59 & 42.03 & 2479.50 & & \\
\hline
\end{tabular}


Tablo 13 incelendiğinde, anne-babalarının $(U=228,000, p<.05)$ ve öğretmenlerinin etkisinde kalan $(\mathrm{U}=76,000, \mathrm{p}<.01)$ öğretmen adaylarının anlamlı olarak kardeşlerinin etkisinde kalan öğretmen adaylarından ve öğretmenlerinin etkisinde kalan öğretmen adaylarının ( $U=359,500, p<.01)$ ise anlamlı olarak arkadaşlarının etkisinde kalan öğretmen adaylarından daha yüksek tutuma sahip oldukları belirlenmiştir.

\section{Sonuç, Tartışma ve Öneriler}

$\mathrm{Bu}$ araştırma sonucunda, sınıf öğretmenliği alanında kadın öğrencilerin öğretmenliğe ilişkin tutumlarının erkeklerinkinden daha yüksek olduğu belirlenmiştir. Literatürde öğretmenlik mesleğine ilişkin tutuma ilişkin yapılan çalışmalar incelendiğinde cinsiyetin önemli bir etken olduğunu ifade eden araştırmaların olduğu görülmektedir. Örneğin Gürbüz ve Kışoğlu (2007) araştırmalarında kadın öğretmen adaylarının öğretmenlik mesleğine ilişkin tutum puan ortalamalarının erkek öğretmen adaylarından daha yüksek olduğunu ifade etmiştir. Benzer şekilde Aydın ve Sağlam (2012), Çapa ve Çil (2000), Pektaş ve Kamer (2011), Tekerek ve Polat (2011), Uğurlu ve Polat (2011) araştırmalarında öğretmenlik mesleğine yönelik tutumları cinsiyet açısından incelediklerinde, kadın öğrencilerin puanlarının erkek öğrencilerden daha yüksek olduğu sonucuna ulaşmışlardır. Kadınlar dünyanın hemen hemen tüm bölgelerinde ilköğretim kademesindeki öğretmenlerin büyük çoğunluğunu oluşturmaktadır (TÜSİAD, 2000). Bir diğer ifade ile dünyanın çoğu yerinde okulların aslında giderek "dişileşen" ortamlar olarak karşımıza çıtı̆̆ bunun ise ilköğretim kademesinde daha yüksek düzeyde olduğu (Tüzel, 2014) göz önüne alındığında, ilköğretim kademesinde görev yapacak olan kadın sınıf öğretmen adaylarının öğretmenlik mesleğine ilişkin olarak erkek öğretmen adaylarından daha yüksek düzeyde tutuma sahip olmalarının aslında beklenen bir durum olduğu söylenebilir.

Araştırma sonuçları incelendiğinde yaş ve sınıf düzeyi arttıkça öğretmen adaylarının mesleğe ilişkin tutum puanlarının düştüğü görülmektedir. Bir diğer ifade ile eğitim fakültesi sıralarına daha olumlu tutumlar ile gelen öğrencilerin mezun olana kadar geçen süreçte tutumlarında negatif yönde bir değişim gözlemlenmektedir. Ancak öğretmenlik mesleğine ilişkin tutum ve öğretmen adaylarının yaşları arasındaki ilişkileri 
inceleyen araştırmalarda ise genellikle tutumun yaşa veya sınıf düzeyine bağlı olarak değişmediği sonucuna ulaşılmıştır (Durmuşçelebi, Yıldız ve Sayg1, 2017; Yaşar Ekici, 2014). Araştırmanın bu bulgusundan farklı olarak Tanel, Şengören ve Tanel (2007) araştırmaları sonucunda öğretmen adayı öğrencilerin öğretmenlik mesleğine ilişkin tutumlarının sınıf düzeyine göre değiştiğini ve sınıf düzeyi arttıkça öğretmen adaylarının tutum puanlarının yükseldiğini belirlemiştir.

Araştırmada öğretmenlik mesleğini üniversiteye giriş sınavında aldıkları puana göre seçen öğretmen adaylarının tutum puanlarının daha düşük olduğu belirlenmiştir. Literatür incelendiğinde öğretmenlik mesleğine ilişkin tutum çalışmalarında sıklıkla dikkati çeken konulardan birinin öğretmen adaylarının öğretmenlik mesleğini tercih etme nedenleri olduğu görülmektedir. Gürbüz ve Kışoğlu (2007) ve Yaşar Ekici (2014)'ye göre öğretmenlik mesleğini seçme nedeni "öğretmen olmak" olan öğretmen adaylarının tutum puanları tercih nedeni çalışma koşulları, iş garantisi, vb. olan öğretmen adaylarından daha yüksektir. Benzer şekilde Dağ (2010) ve Nalçacı ve Sökmen (2016) da araştırmalarında öğretmen adaylarının öğretmenlik mesleğini seçme nedenlerinin mesleğe ilişkin tutum puanlarını etkilediği sonucuna ulaşmışlardır. Ürün Karahan ve Erdağı Toksun (2018) ise araştırmalarında formasyon eğitimi alan öğretmen adaylarının mesleği seçme sebeplerinin "mesleği sevme" kodu çerçevesinde şekillendiğini; Türkçe Eğitimi Bölümünde okumakta olan öğretmen adaylarının ise "puanın bu bölüme yetmesi" kodu çerçevesinde ortaya çıktığını ifade etmişlerdir.

Çocukluk döneminde hangi mesleği seçeceğine ilişkin bir fikrin oluşmaya başlamasından, yetişkinlikte bir meslek edinmeye ve o mesleği yapmaya başlayana kadar süren gelişim dönemlerini kapsayan mesleki gelişim sürecini etkileyen en önemli faktörlerden biri bireyin ailesi ve etkileşim içinde olduğu diğer kişilerdir (MEB, 2015). Bu araştırmanın sonuçları incelendiğinde de aile desteğinin öğretmen adaylarının mesleki tutumunu olumlu yönde etkilediği görülmüştür. Bu bağlamda ailelere ilişkin mesleki bilgilendirme çalışmalarının ve okul-aile işbirliğinin öğrencinin eğitim-öğretim hayatına başladığı ilk yıllardan itibaren olmakla birlikte, gerek öğretmen adaylarının eğitim görecekleri lisans programını seçtikleri gerekse öğretmenlik lisans programlarına devam ettikleri süreçlerde de önem taşıdığı söylenebilir. 


\section{Öneriler}

- Öğretmen adaylarının mesleki tutumlarının belirlendiği bu araştırma nicel araştırma yöntemleri çerçevesinde yapılandırılmıştır. Nitel yöntem ve teknikler kullanılarak öğretmen adaylarının mesleğe ilişkin tutumlarına ilişkin derinlemesine bilgi edinilebilir.

- Öğretmen adaylarının mesleki tutum puanları mesleği seçme nedenlerinden etkilenmektedir. Bu nedenle orta öğretim düzeyinde mesleki rehberlik çalışmalarına ağırlık verilmesi ve mesleğe ilişkin olumlu tutumları olan öğrencilerin eğitim fakültesine yönlendirilmesi önemli görülmektedir. Öğretmenlerin mesleklerine yönelik tutumlarının, onların mesleklerini nasıl ve hangi nitelikte yapacaklarını dolayısıyla yetiştirecekleri nesilleri ve toplumu doğrudan etkileyen önemli unsurlardan biri olduğu söylenebilir. Bu nedenle öğretmenlik mesleğini seçerek eğitim fakültesine gelmiş olan öğretmen adaylarının öğretmenlik mesleğini bir zorunluluğun ötesinde gerçekten isteyerek tercih etmeleri, mesleklerini şevkle ve mesleğe gönül vererek icra etmeleri beklenmektedir. Bu bağlamda öğretmenlik mesleğinin gerek öğrencilerin gerekse öğrencileri yükseköğrenim kurumlarını tercihleri esnasında etkileyen ve yönlendiren ailelerin MEB ve eğitim fakülteleri işbirliğiyle düzenlenebilecek olan mesleki tanıtım toplantıları ile öğretmenlik mesleği hakkında detaylı biçimde bilgilendirilmesi önerilebilir.

- Araştırma bulgularına göre öğretmenlik mesleğini tercih etmede öğretmen adaylarını en fazla etkileyen kişiler olarak karşımıza çıkan öğretmenlerin iyi birer rol model olması ve öğrencilerini iyi gözlemleyerek öğretmenlik mesleğine uygun öğrencilerini mesleğe yönlendirmesi ve özendirmesi de oldukça önemlidir 
EXTENDED ABSTRACT

\title{
Classroom Teacher Candidates'Attitudes towards Teaching Profession
}

\author{
Emel Tüzel İşeri - Hilal Kahraman - Nazife Karadağ \\ Gaziosmanpaşa University, Cumhuriyet University, Adıyaman University
}

Attitude is the tendency that creates the emotions, thoughts and behaviors of a person against a psychological object. Although it cannot be said that only attitudes cause behavior, there is a certain attitude on the basis of behavior. When evaluated from this aspect, it can be said that the attitudes of teachers towards the teaching profession have an important role in their professional performance (Erdem, Gezer and Çokadar, 2005: 471).Teacher qualifications are defined as the knowledge, skills and attitudes teachers should have in order to perform their professions effectively and efficiently (MEB, 2017-b). Teacher qualifications cannot be explained only by having general culture, field knowledge and teaching professional knowledge. In addition, teachers' affective responses and attitudes towards their profession also play an important role in the success of the teaching profession. Also in "General Qualifications of Teaching Proficiency" attitudes and values, professional knowledge and professional skills are defined as competence areas (MEB, 2017-b).

The purpose of this study is to examine pre-service teachers' attitudes towards teaching profession in terms of various personal variables. This study is a research in descriptive survey model which shows how attitudes of pre-service teachers in the classroom teaching program have changed according to various personal variables they have. Participants consist of 323 teacher candidates who studied at three different faculties in Turkey in the study universe was selected by using easily accessible sampling method. Criterion sampling method was used at class level. Participants included in the study are 1st and 4th grade students.

The data collection tool consists of two parts. In the first part, "The personal variables form" which includes demographic information of the teacher candidates have been formed by the researchers in accordance with the sub-problems of the research. The second part of the data collection 
tool was "Attitude Scale of Teaching Profession" which was developed by Üstüner (2006).

As a result of this research, it was determined that the attitudes of female students towards teaching was higher than that of males in the field of classroom teaching. In the literature, it is seen that there are researches indicating that gender is an important factor when the studies on the attitude towards teaching profession are examined. For example, Gürbüz and Kışoğlu (2007) stated that female teacher candidates' attitude point averages were higher than male teacher candidates. Similarly, when Aydın and Sağlam (2012), Çapa and Çil (2000), Pektaş and Kamer (2011), Tekerek and Polat (2011), Uğurlu and Polat (2011) examined attitudes towards teaching profession in terms of gender, the results indicated that the female students' scores were higher than the male students.

When the results of the research are examined, it is seen that the attitude scores of the teacher candidates decreased as the grade level and age increased. In other words, a negative change is observed in the attitudes of the students who come with more positive attitudes towards the faculty of education. However, in studies investigating the relationship between the attitude of the teaching profession and the age of the teacher candidates, it was generally concluded that the attitude did not change according to age or class level (Durmuşçelebi, Yildiz and Saygi, 2017; Yasar Ekici, 2014). Unlike the findings of this study, the results of the research conducted by Tanel, Şengören and Tanel (2007) indicated that the attitudes of the teacher candidates towards the teaching profession changed according to the grade level and the attitude scores of the teacher candidates increased as the class level increased.

When the literature is examined, it is seen that one of the subjects that are frequently noticed in the attitude studies related to the teaching profession is the reasons for pre-service teachers to prefer the teaching profession. In this research, it was determined that the attitude scores of the teacher candidates who chose the teaching profession accpording to their university enterance exam scores were lower than the other ones.

According to this study, it was seen that family support positively affected the professional attitude of the teacher candidates. In this context, 
it can be said that vocational information activities and school-family cooperation related to families are important since the beginning of the education period of the students.

This research, in which professional attitudes of prospective teachers are determined, was structured within the framework of quantitative research methods. In-depth knowledge about the attitudes of teacher candidates towards the profession can be obtained by using qualitative methods and techniques. The professional attitude scores of teacher candidates are affected by the reasons for choosing the profession. Therefore, it is necessary to focus on vocational guidance at the level of secondary education.

\section{Kaynakça / References}

Akgün, F. ve Özgür, H. (2014). Bilişim teknolojileri öğretmen adaylarının öğretmenlik mesleğine ilişkin tutumları ile mesleki kaygılarının incelenmesi. Eğitimde Kuram ve Uygulama, 10(5), 1206-1223.

Akpınar, E., Yıldız, E. ve Ergin, Ö. (2006). Fen Bilgisi öğretmen adaylarının öğretmenlik mesleğine ilişkin tutumları. Buca Eğitim Fakültesi Dergisi, $19,56-62$.

Alım, M. ve Bekdemir, Ü. (2006). Coğrafya öğretmeni adaylarının öğretmenlik mesleğine ilişkin tutumları, Milli Ĕ̆itim Dergisi, 172, 263-275.

Aydın, R. ve Sağlam, G. (2012). Öğretmen adaylarının öğretmenlik mesleğine ilişkin tutumlarının belirlenmesi. Türk Eğitim Bilimleri Dergisi, 10(2), 257-294.

Bozdoğan, A.E., Aydın, D. ve Yıldırım, K. (2007). Öğretmen adaylarının öğretmenlik mesleğine ilişkin tutumları. Ahi Evran Üniversitesi Kırşehir Eğitim Fakültesi Dergisi (KEFAD), 8(2), 83-97.

Brown, M. M. (1992). Caribbean first-year teachers' reasons for choosing teaching as a career. Journal of Education for Teaching, 18(2), 185-195.

Çapa, Y. ve Çil, N. (2000). Öğretmen adaylarının öğretmenlik mesleğine ilişkin tutumlarının farklı değişkenler açısından incelenmesi. Hacettepe Üniversitesi Ĕ̆itim Fakültesi Dergisi, 18, 69-73.

Çelenk, S. (1988). Eğitim yüksek okulu öğrencilerinin öğretmenlik mesleğine ilişkin tutumları. Yüksek Lisans Tezi, Selçuk Üniversitesi, Sosyal Bilimler Enstitüsü, Konya. 
Çetinkaya, Z. (2009). Türkçe öğretmen adaylarının öğretmenlik mesleğine ilişkin tutumlarının belirlenmesi. Ilköğretim Online, 8(2), 298-305.

Çiğdem, G. ve Memiş, A. (2011). Sınıf öğretmenliği adaylarının öğrenme stilleri ve öğretmenlik mesleğine ilişkin tutumlarının çeşitli değişkenler açısından incelenmesi. Çukurova Üniversitesi Ĕ̆itim Fakültesi Dergisi, $3(40), 57-77$.

Dağ, E. (2010). Sinı öğretmeni adaylarının öğretmenlik mesleğine ilişkin tutumları ile öğretmenlik mesleğini tercih etmelerinde etkili olan faktörler arasındaki ilişki:İzmir ili örneği. Yayınlanmamış yüksek lisans tezi, Ege Üniversitesi, İstanbul.

Dikmen, M. ve Tuncer, M. (2018a). Öğretmenlik mesleğine ilişkin tutumun çeşitli değişkenlere göre değerlendirilmesi, Harran Education Journal, 3(1), 24-38.

Dikmen, M. ve Tuncer, M. (2018b). Bilgi okuryazarlık özyeterliği inancı, öğretmenlik mesleğine ilişkin tutum ve üst biliş düşünme becerileri arasındaki ilişkiler, Elektronik Ĕ̆itim Bilimleri Dergisi, 7(13), 73-86.

Durmuşçelebi, M., Yıldız, N., ve Saygı, E. (2017). Öğretmen adaylarının öğretmenlik mesleğine ilişkin tutumlarının bazı değişkenler açısından incelenmesi. Uluslararası Toplum Araştırmaları Dergisi, 7(12), 8-12.

Durmuşoğlu, M.C., Yanık, C. ve Akkoyunlu, B. (2009). Türk ve Azeri öğretmen adaylarının öğretmenlik mesleğine ilişkin tutumları. Hacettepe Üniversitesi Ĕ̆itim Fakültesi Dergisi (H.U.Journal of Education), 36, 7686.

Erdem, A.R., Gezer, K. ve Çokadar, H. 2005. Ortaöğretim fen-matematik ve sosyal alanlar öğretmenliği tezsiz yüksek lisans öğrencilerinin öğretmenlik mesleğine ilişkin tutumları. 14. Ulusal Ĕ̆itim Bilimleri Kongresi Bildiri Kitabı içinde (s.471-477), 28-30 Eylül 2005. Denizli

Gürbüz, H. ve Kişoğlu, M. (2007). Tezsiz yüksek lisans programına devam eden fen-edebiyat ve eğitim fakültesi öğrencilerinin öğretmenlik mesleğine ilişkin tutumları:Atatürk Üniversitesi örneği. Erzincan Ĕ̆itim Fakültesi Dergisi, 9(2), s.71-83.

Hançer, A. H. (2017). Fen bilgisi öğretmen adaylarının öğretmenlik mesleğine ilişkin tutumlarının akademik sahtekârlık eğilimleri üzerindeki etkisi. Electronic Turkish Studies, 12(6), 387-402.

Kağıtçıbaşı, Ç. (2006). Yeni insan ve insanlar. 10. Basım. İstanbul: Sistem Matbaacilik. 
Kahyaoğlu, M., Tan, Ç. ve Kaya, M. F. (2013). İlköğretim öğretmen adaylarının öğrenme stilleri ve öğretmenlik mesleğine ilişkin tutumları. Mustafa Kemal Üniversitesi Sosyal Bilimler Enstitüsü Dergisi, 10(21), 225-236.

Karasar, N. (2009). Bilimsel araştırma yöntemi: Kavramlar, ilkeler, teknikler. Nobel Yayın Dağıtım.

MEB (1973). Milli Eğitim Temel Kanunu. Xx.xx.xxxx tarihinde http://www.mevzuat.gov.tr/MevzuatMetin/1.5.1739.pdf adresinden erişilmiştir.

MEB (2015). Mesleki eğilime göre yönlendirme ve kariyer rehberlĭgi projesi. Ankara ve Kastamonu'da yapılan eğiticiler eğitiminin ders notları. https://www.kariyerrehberligi.net/upload/dokumanlar/EgiticiNotlari.pdf adresinden 29.04.2019 tarihinde erişim sağlanmıştır.

MEB (2017-a). Öğretmen Strateji Belgesi (2017-2023). https://oygm.meb.gov.tr/meb iys dosya$\underline{\text { lar/2017 07/26174415 Strateji Belgesi RG-Ylan- 26.07.2017.pdf }}$ adresinden 29.04.2019 tarihinde erişim sağlanmıştır.

MEB (2017-b). Öğretmenlik Mesleği Genel Yeterlilikleri. https://oygm.meb.gov.tr/meb iys dosyalar/2017 12/11115355 YYRETMENLYK MESLEYY GENEL YETERLYKLERY.pdf adresinden 29.04.2019 tarihinde erişim sağlanmıştır.

MEB (2018). 2023 Eğitim Vizyonu. http://2023vizyonu.meb.gov.tr/doc/2023 EGITIM VIZYONU.pdf adresinden 29.04.2019 tarihinde erişim sağlanmıştır.

Nalçacı, A. ve Sökmen, Y. (2016). Öğretmen adaylarının mesleği tercih nedenleri ve öğretmenlik mesleğine ilişkin tutumları arasındaki ilişki, Ahi Evran Üniversitesi Kırşehir Eğitim Fakültesi Dergisi, 17(3), 717-727.

Serdar, E., Harmandar-Demirel, D. Ve Demirel, M. (2018). Beden eğitimi öğretmeni adaylarının mesleğe ilişkin tutumlarının belirlenmesi. International Journal of Human Sciences, 15(4), 2190-2197.

$\mathrm{Su}, \mathrm{Z}$. (1997). Teaching as a profession and as a career: minority candidates' perspectives. Teaching ETeacher Education, 13(3), 325-340.

Tanel, R. , Şengören, S. K. Ve Tanel, Z., (2007). Fizik öğretmen adaylarının öğretmenlik mesleğine ilişkin tutumlarının farklı değişkenler açısından incelenmesi. Pamukkale Üniversitesi Ĕ̆itim Fakültesi Dergisi, 22, 19. 
Tekerek, M. ve Polat, S (2011). Öğretmen adalarının öğretmenlik mesleğine ilişkin tutumları. 5 th International Computer \& Instructional Technologies Symposium, 22-24 September 2011. Frrat University-Elazığ

Temizkan, M. (2008). Türkçe öğretmeni adaylarının öğretmenlik mesleğine ilişkin tutumları üzerine bir araştırma. Türk Ĕ̆itim Bilimleri Dergisi, 6(3). 461-486.

TDK (2009). Meslek. http://sozluk.gov.tr/ adresinden 23.08.2019 tarihinde erişim sağlanmıştır.

Toprakçı, E. (2009). Öğretmenlerin suç karnesi :Yarg1 kararlı gazete haberleri ölçütünde karşılaştırmalı bir analiz. IV. Ulusal Ĕ̆itim Yönetimi Kongresi Bildiriler Kitabı, 14-15 Mayıs 2009, Denizli, Türkiye.

TÜSİAD (2000). Kadın-erkek eşitliğine doğru yürüyüş: Eğitim, çalışma yaşamı ve siyaset. İstanbul: TÜSİAD. Yayın no: TÜSİAD-T/2000-12/290.

Tüzel, E. (2014). Eğitim örgütlerinde kadın yöneticilerin kariyer engellerinin incelenmesi:Ankara ili örneği. Yayımlanmamış doktora tezi, Gazi Üniversitesi, Eğitim Bilimleri Enstitüsü, Ankara.

Uğurlu, C. T. ve Polat, S.(2011). Sınıf öğretmenliği öğrencilerinin öğretmenlik mesleğine ilişkin tutumları. C. Ü. Sosyal Bilimler Dergisi, 35(1), 68-74.

Üstün, E., Erkan S. ve Akman B. (2004). Türkiye'de okul öncesi öğretmenliği öğrencilerinin öğretmenlik mesleğine ilişkin tutumlarının incelenmesi. Kırgizistan-Türkiye Manas Üniversitesi Sosyal Bilimler Dergisi, 10, 129-136.

Üstüner, M. (2006). Öğretmenlik mesleğine ilişkin tutum ölçeğinin geçerlik ve güvenirlik çalışması, Kuram ve Uygulamada Ĕ̆itim Yönetimi, 45, 109127.

Ürün Karahan, B. ve Erdağı Toksun, S. (2018). Eğitim fakültesi ve pedagojik formasyon gruplarındaki öğretmen adaylarının öğretmenlik mesleğine ilişkin tutumlarının ve görüşlerinin değerlendirilmesi. Uluslararası Türkçe Edebiyat Kültür Eğitim Dergisi, 7(3), 1976-1994.

Yaşar-Ekici, F. (2014). Öğretmen adaylarının öğretmenlik mesleğine ilişkin tutumlarının çeşitli değişkenler açısından incelenmesi (İstanbul Sabahattin Zaim Üniversitesi örneği). Uluslararası Sosyal Araştırmalar Dergisi, 7(35), 658-665.

Zembat, R., Akşin-Yavuz, E., Tunçeli, H. İ. veYılmaz, H. (2018). Öğretmenlik mesleğine ilişkin tutum ile akademik motivasyon ve başarı arasındaki ilişkinin incelenmesi, Kuramsal Ĕ̆itimbilim Dergisi, 11(4), 789-808. 


\section{Kaynakça Bilgisi / Citation Information}

Tüzel-İşeri, E., Kahraman, H. ve Karadağ, N. (2019). Sınıf öğretmeni adaylarının öğretmenlik mesleğine ilişkin tutumları. OPUSUluslararası Toplum Araştırmaları Dergisi , 13(19), 682-705. DOI: 10.26466/opus.567283 